\title{
FOREIGN DIRECT INVESTMENTS IN THE PERIOD 2004-2017: THE CASE OF THE CZECH REPUBLIC
}

\author{
[Př́imé zahraniční investice na př́ikladu ČR za období 2004-2017]
}

\author{
Š́rka Pindorová ${ }^{1}$ \\ ${ }^{1}$ Slezská univerzita, Obchodně podnikatelská fakulta, Univerzitní nám. 1934/3, 73340 Karviná \\ Email: sarka.pindorova@seznam.cz
}

\begin{abstract}
This article discusses the development of foreign direct investments for the period 2004 to 2017 in the Czech Republic. In 2004, the Czech Republic joined the EU and the government began to focus on investment incentives to attract foreign firms, attracting foreign capital. The subject matter of the study will be the development of changes in the FDI status of core capital, reinvested earnings and other capital. The aim will be to find out how the FDI, investment incentives and foreign-controlled enterprises for the period 2004-2017 in the Czech Republic developed. A detailed breakdown by country of investors and the number of employees will determine which countries and sectors are most affected by foreign direct investment. The Czech Republic is considered an attractive country for investors from the Netherlands, Austria and Germany. These countries have the largest share of capital inflows in the capital inflow over the period, particularly in financial services and manufacturing.
\end{abstract}

Keywords: financial globalization, international investment, multinational firms, role of international organizations.

JEL classification: F21, O19, F21, F23

Received: 18.10.2018; Reviewed: 3.11.2018; 12.11.2018; Accepted: 6.3.2019

\section{Úvod}

Př́liv přímých zahraničních investic (PZI) v mnohém vypovídá o zdraví hostitelské ekonomiky. Obecné povědomí o zahraničních investicích je takové, že mohou mít pozitivní dopady na cílové ekonomiky. Ekonomové se domnívají, že zvýšený zahraniční kapitálový tok do tuzemské ekonomiky má za následek celkové zefektivnění know-how, moderní technologie země a posílení tuzemské ekonomiky. Mnoho zemí liberalizovalo svou zahraniční politiku a soustředilo se na přilákání zahraničních investic. Česká republika (ČR) $\mathrm{v}$ devadesátých letech patřila $\mathrm{k}$ zemím, které procházely transformací z centrálně plánované ekonomiky na tržní ekonomiku. Docházelo k velkým změnám, kdy např́íklad v centrálně plánované ekonomice byla povinnost pracovat a oficiálně neexistovala nezaměstnanost, ale v tržní ekonomice se zaměstnanost vyvíjí dle trhu práce. Přelomovým obdobím pro ČR byla změna 90. let, protože došlo k velkým změnám. Byla kuponová privatizace, došlo $\mathrm{k}$ liberalizaci cen a byla změna vnější ekonomických vztahů. Po roce 1990 se projevil značný pokles zaměstnanosti v národním hospodářství. Do roku 1998 v ČR byla centrálně plánovaná ekonomika. Od tohoto roku se postupně zaváděly reformy s cílem přechodu na tržní systém. V letech 1996-1999 se pozvolna uskutečňoval proces restrukturalizace zejména ve zpracovatelském průmyslu, který by měl být motorem ekonomického růstu a exportní výkonnosti. Velkými strukturálními změnami procházela česká ekonomika. Otevírala se národní ekonomika, pro rychlejší rozvoj ekonomiky už nebyl dostačující pouze český kapitál, ale také zahraniční kapitál. Česká ekonomika se v letech 2000-2004 dostala na dráhu dynamického a relativně stabilního vývoje, protože v tomto období si domácí poptávka stále uchovávala předstih př̀ed růstem HDP. Proces transformace ČR završil vstup do Evropské unie (EU). (Kunešová 2014) 
ČR se připojila na globální trhy a zapojila se do společenství ekonomicky otevřených zemí. Formování české ekonomiky je ovlivňováno př́livem zahraničních investic a problematika PZI byla často diskutovaným tématem na různých úrovních, což je důvodem této výzkumné studie. Z všeobecného pohledu v literatuře panuje jakýsi konsenzus o pozitivních efektech PZI na domácí ekonomiku. Empirické analýzy však potvrzují, že tato oblast výzkumu není jednoznačná a jednoduchá. Mezi makroekonomické efekty dle Holmana (2004) patří veličiny, jimiž jsou úroveň HDP, míra inflace, vnější ekonomická pozice a míra nezaměstnanosti. Efekty PZI mohou působit na ekonomiku dané země př́ímo či nepř́ímo a zároveň pozitivně či negativně. Tento makroekonomický pohled nebude předmětem zkoumání tohoto článku.

U provedeného výzkumu vycházím s definice malých a středních podniků dle Evropské komise: Kategorie mikro podniků, malých a středních podniků je založena z podniků, které zaměstnávají méně než 250 osob a jejich roční obrat nepřesáhuje 50 miliónu EUR, anebo jejichž bilanční suma roční rozvahy nepřesahuje 43 milionů EUR. (Evropská komise 2015).

První kapitola se věnuje přehledu literatury autorů, kteří se věnovali PZI a IP. Druhá kapitola se zabývá metodikou zpracování výzkumné práce. V třetí kapitole jsou vyhodnoceny empirické výsledky. Ve čtvrté kapitole jsou shrnuty zjištěné výsledky a okomentovány data zkoumaných veličin a popsán vývoj investic v období 2004-2017. V závěru jsou popsány zjištěné údaje a uvedeny možné doporučení pro další výzkumy.

Rozvoj ekonomiky lze posuzovat na základě vývoje nejrůznějších veličin. Bude provedena analýza následujících veličin: PZI, podniky pod zahraniční kontrolou a IP za období 2004 2017 na území ČR. Cílem bude zjistit, jak se vyvíjely PZI u jednotlivých komponentů, které země původů měly největší podíl na PZI a v jakém množství docházelo k čerpání investičních pobídek. Bude zkoumáno, kolik vzniklo podniků pod zahraniční kontrolou a tyto podniky budou rozděleny dle kritéria počtu zaměstnanců do jednotlivých skupin. Na základě podrobné analýzy zkoumaných veličin dle země investorů a dle odvětví bude zjišt'ováno, které země a které odvětví nejvíce ovlivňují PZI.

\section{Přehled literatury}

Tématu PZI se věnuje řada autorů a bylo k tomu napsáno velké množstí studií. Zákadní vymezení PZI je definované v devizovém zákoně (Zákon č.219/1995 Sb., odst. 1 ad i)) a pojetí PZI je následující: PZI odráží záměr rezidenta jedné ekonomiky získat trvalou účast v subjektu, který je rezidentem v ekonomice jiné, než je ekonomika investora. Culem (1988) zkoumal dopad velikosti trhu pro 14 zemí za období 1969-1982. Došel ke zjištění, že větší trh umožňuje snadnější zachycení výhod velkokapacitní výroby. Podle outsourcingu hypotéza (Feenstra a Hanson 1996) konstastuje nárůst dovozu meziproduktů a to vyplývá ze strategií společností přemístit část své produkce do zahraničí s prríslušnými komparativními výhodami. Goldberg (1997) shledává rostoucí závislost na dovezených vstupních produktech téměř ve všech výrobních odvětvích ve Spojených státech, ve Spojeném království a v Kanadě. Ale je zajímavé, že ne v Japonsku. Dalším důkazem, že velká část zahraničních investic je spíše horizontální než vertikální a zjištění, že prodej zahraničních poboček je vyšší v zemích s vyššími tarify a náklady na dopravu se zabýval Brainard (1997). Početné studie zahraničních obchodů jsou založené na klíčovém díle Markusena a Venablesa (1998) a vysvětlují př́ímé zahraniční investice $(\mathrm{PZI})$ z pohledu volby investorů. Navíc investoři přirozeně preferují rychlejší rostoucí trhy, které nabízejí slibnější vyhlídky. 
Základní taxonomie PZI, kterou uvádí Markus (1998) je používána i v rámci OECD a UNCTAD. Vychází ze čtyř oblastí: míra kontroly (podniky s menšinovým zahraničním podílem a podniky pod zahraniční kontrolou). Motiv vstupu, což jsou faktory, které vyhledávají aktiva a další je způsob vstupu a specializace mateřské firmy. Pohledy od různých autorů se však liší v tom, jak velký význam získal vnitropodnikový obchod v posledních desetiletích. Žigič (1998) z ekonomického institutu CERGE-EI tyto efekty rozděluje následovně: transfer know-how, imitace domácími firmami, stanovení nových standardů a vzdělávání. Billington (1999) je prvním autorem, který považuje populaci za proměnnou, používá hustotu obyvatelstva jako rozhodující faktor. Tvrdí, že čím větší je celkový př́ijem a potenciál rozvoje v oblasti hostitelské oblasti (země, regionu a sub regionu), tím větší je výše investice do PZI.

V oblasti střední a východní Evropy se věnoval výzkumu efektu PZI na domácí investice s využitím firemních dat Konings (2000). Použil data od více než 5000 firem z Bulharska, Rumunska a Polska za časové období 1993-1997. Hlavním záměrem bylo zjistit, jestli firmy vlastněné zahraničním investorem realizují svoji podnikatelskou činnost efektivněji než domácí firmy, a jestli dochází k technologickému transferu ze zahraničních firem na domácí podniky. Byl dokázán vytěsňovací efekt investic v Rumunsku a Bulharsku a naopak tento efekt nebyl prokázaný v Polsku. Statisticky významný př́mý technologický transfer byl zjištěn pouze v př́padě Polska. Na základě firemních dat zjišstovali Djankov a Hoekman (2000) efekt PZI na domácí investice a prokázali existenci přímého a nepř́mého technologického transferu v ČR. Výzkum byl zrealizovan pomoci panelové regrese za časové období 1992 - 1996. Byl dokázán prrímý technologický transfer a efekt vytěsňování domácích investic. Naopak nepodařilo se prokázat existence nepř́mého technologického transferu. Hanson (2000) také naznačuje, že nadnárodní společnosti (MNE) jsou stále vertikálněji integrovány a shledává, že to má často podobu následných distribučních činností zaměřených na domácí a jiné regionální trhy než skutečnou výrobní činnost.

Chakrabarti (2001) se zaměřuje na zkoumání dopadu velikosti trhu na PZI s ohledem na velikost populace a její charakteristiky v rozvojových zemích $\mathrm{v}$ teoretické a empirické rovině. Na druhou stranu Asiedu (2002) dospěl k závěru, že velikost trhu není pro rozvojovou zemi rozhodující pro nízké příjmy. Podobným výzkumem se také zabývali Backer a Sleuwaegen (2003). Ve svoji práci se zaměřil na zkoumání vlivu PZI na domácí podniky ve zpracovatelském průmyslu v Belgii za období 1990-1995. Došel k podobným empirickým závěrům jako ve výše zmíněné studii, že efekt vytěsňování domácích fïrem je jen krátkodobý. Ríman (2008) konstatoval, že těmito faktory jsou zejména: politická stabilita, kvalitní zákonodárství, kvalitní infrastruktura, levná a vzdělaná pracovní síla s dobrými pracovními návyky a geografická poloha. Tomšík (2008) se věnoval tomuto tématu a zjistil, že PZI nemohou být samostatným cílem. Mohou být nanejvýš zprostředkujícím cílem, ale skutečný cíl je nutné definovat standardně například pomocí růstu ekonomiky nebo zaměstnanosti. Podstatné tak je, jaký je vztah mezi PZI a makroekonomickým vývojem.

Tomšík (2008) došel k závěrům, že účinky PZI nejsou tak pozitivní, jak si někteří ekonomové a tvůrci hospodářské politiky slibovali. Kam povede př́liv PZI, popsala podrobně Zamrazilová (2008). PZI zvýšily investiční potenciál české ekonomiky vysoko nad vlastní možnosti. Jahn (2008) považuje zahraniční investice za jednoznačně příznivý faktor, který výrazně ovlivnil pozdější ekonomický vývoj v ČR, zásadně přispěl $\mathrm{k}$ dlouhodobě vysokému růstu HDP a rychlému poklesu nezaměstnanosti, oživení zahraničního obchodu a zvýšení přidané hodnoty a produktivity práce. 
V měsíčníku Hospodářské komory ČR (2008) bylo uvedeno, že v ČR je přeinvestováno. Chybí nám kvalifikovaná pracovní síla. Pro další významné investory zde není príliš prostoru. Kosová (2010) zkoumá vliv PZI na základě panelového souboru firemních dat (přes 11000 firem). Tyto údaje byly získány za časové období 1994 - 2001. Byly zkoumány vlivy př́tomnosti zahraničních firem v ČR, a jak to ovlivňovalo růst a přežití domácích firem. Nicméně bylo dokázáno, že vytěsňovací efekt je jen krátkodobý. V této části jsou uvedeni autoři, kteří se zabývali investičními pobídkami a daněmi. Základní vymezení investičních pobídek je definované v zákoně o IP. (Zákon č. 72/2000 Sb.) Investiční pobídka je sleva na dani $\mathrm{z}$ př́ijmů, převod technicky vybaveného území za zvýhodněnou cenu. Zárověň $\mathrm{s}$ IP jsou spojeny zvláštní podmíky, které musí být dodrženy, aby firma mohla uplatint slevu na dani, která se rovná vypočtené dani z př́ijmů. Begg a McDowall (1987) uvádí přehled několika studií, které se př́mo nebo neprímo dotýkají vlivu regionálních investičních pobídek na investiční chování firem v podporovaných oblastech Spojeného království. V souvislosti s rozvojovými zeměmi mohou mít pobídky význam zejména pro exportní průmysl. IP pomáhají k rozšiřrení firem do dalších oblastí. Lahiri a Ono (1996) konstatují, že hostitelské země, které jsou atraktivní a mají dobré podnikatelské prostředí.

Haufler a Wooton (1999) analyzují daňovou konkurenci mezi dvěma zeměmi s nerovnou velikostí. Manasan R. (2000) dospěl k tomu, že nejdůležitějšími druhy fiskálních pobídek jsou ty, které mají formu osvobození od daně z příjmů a osvobození od dovozního cla. Morisset a Pirnia (2000) jsou přesvědčeni, že IP jsou méně účinné než infrastruktura. Rozdílné daně v různých zemích mohou mít vliv na rozhodnutí investorů. Dopad daňové politiky na PZI je spíše omezen, alespoň ve srovnání s jinými faktory, jako je politická stabilita, náklady na dostupnost práce a základní infrastruktura. Chalk (2001) a Medalla (2002) se pokoušeli odhadnout ztráty $\mathrm{z}$ celkových př́imů $\mathrm{v}$ důsledku fiskálních pobídek. Je potřeba si uvědomit vysoké náklady a přistupovat opatrně při poskytování pobídek. Chalk (2001) došel k závěrům, že pobídky mají rozdílné a protichůdné účinky na rozhodování investorů. Co se týče PZI dle Medalla (2002) mohou fiskální pobídky teoreticky zvýšit celkovou hodnotu investice a přilákat zahraniční investory.

Banga (2003) zkoumal ekonomický vliv hostitelských zemí. Např́klad velikost trhu, náklady na pracovní sílu, vzdělávání atd. Zjistil, že nižšś daně přitahují PZI z rozvojových zemí, ale nižší daně nepřitahují PZI z rozvinutých zemí. Navíc bilaterální investiční smlouvy s rozvinutými zeměmi se zdají být silné a významné pro dopad na PZI, zatímco v př́padě BIT s rozvojovými zeměmi je pravdou opak. Nicméně studie Blomström \& Kokko (2003) naznačují, že použití investičních pobídek (IP) k přilákání zahraničních firem nemusí být sociálně optimální. Studie Hardinga a Javorčíka (2007) předložila důkazy o odklonu PZI do jiných sousedních zemí kvůli IP. Nutno posílit schopnost místních firem realizovat výnosy z PZI. Daňová sazba negativně souvisí s PZI. Drábek (2007) navrhuje, aby se Česko vydalo motivující cestou k dalšímu rozvoji ekonomiky. Prostřednictvím snižování daní, zjednodušení právního prostředí, posílení právních jistot, zlepšení infrastruktury a celkové zatraktivnění podnikatelského klimatu. Na základě vypracované regrese od Cleeve (2008) výsledky ukázaly, že zahraniční investory ovlivnňují vládní politiky a daňové prázdniny. Madiès a Dethier (2010) tvrdí, že IP zvyšují investice, vytvářejí nové pracovní místa a mají vliv na pozitivní externality. A to daň z př́ijmů a stabilní politickou situaci. 


\section{Metodologie a data}

V této části jsou popsány metody použité v tomto článku. Analýza vědecké literatury, metody generalizace a systematizace jsou použity $\mathrm{k}$ identifikaci různých metod a postupů. V první fázi je provedená kritická rešerše $\mathrm{k}$ tomuto tématu a představena a zhodnocena daná problematika, jež se zaměřuje na PZI a jejich vývoj ve sledovaném období. Následně je proveden sběr a analýza dostupné odborné domácí a zahraniční literatury. V této práci je také využita metoda komparace za účelem ověření dosažených výsledků či závěrů. V rámci této práce se bude pracovat s veřejnými ročními daty za období 2004-2017. Začátek zkoumaného období byl zvolen rok vstupu ČR do EU. Jedná se o přelomový rok pro podnikatelské prostředí. Zejména z pohledu ekonomického rozvoje země a přilákání zahraničních investorů do ČR.

Základním souborem jsou právnické osoby sídlící v ČR pod zahraniční kontrolou. V rámci této práce jsou řešeny PZI v rámci ČR, kdy se vychází $\mathrm{z}$ definice dle devizového zákona v ČR. Firmy dle počtu zaměstnanců budou rozděleny na mikro podniky ( 0 až 9 zaměstnanců) $\mathrm{s}$ ročním obratem nebo bilanční sumou do 2 mil EUR. Malé podniky (10 až 49 zaměstnanců) s ročním obratem nebo bilanční sumou do 10 mil. EUR, střední podniky $(50$ až 249 zaměstnanců) s ročním obratem 50 mil. EUR nebo s bilanční sumou do 43 mil. EUR. Všechny firmy nad 250 zaměstnanců jsou považovány za velké podniky. PZI jsou členěny podle odvětvové struktury CZ-NACE. Analyzovaná data jsou získána z databáze ČSÚ, CzechInvest a $\mathrm{z}$ databáze Ministerstva průmyslu a obchodu. $\mathrm{Z}$ pohledu devizového zákona (Zákon č.219/1995 Sb., odst. 1 ad i)) je prŕmou investicí při plnění oznamovací povinnosti takové vynaložení peněžních prostředků nebo jiných penězi ocenitelných majetkových práv a jiných majetkových hodnot, jehož účelem je založení, nabytí nebo rozšíření trvalých ekonomických vztahů. Struktura PZI je vyjádřena v následujícím vztahu:

$$
\text { PZI = základní kapitál + reinvestovaný zisk + ostatní kapitál }
$$

Základní kapitál představuje vklad investora do základního (vlastního kapitálu) dané společnosti. Reinvestovaný zisk je podíl zahraničního investora na nerozděleném hospodářském výsledku formou dividend. Ostatní kapitál v sobě zahrnuje objem úvěrů, včetně dluhových cenných papírů a to mezi přímým investorem a afilovanými podniky či ostatními podniky ve skupině. Příliv PZI je jedním ze zrojů financování podniků.

\section{Empirické výsledky}

V rámci této práce jsou řešeny PZI, kdy se vychází z definice dle devizového zákona v ČR. Po rozpadu komunistického režimu v roce 1989 voblasti podnikání byl zaznamenán nedostatek kapitálu, nových technologii a know-how. V těchto letech začala privatizace, ve které docházelo k prodeji státního majetku a to zejména do vlastnictví zahraničních investorů. Investiční stimuly byly vytvořeny tak, aby domácí i zahraniční investoři měli stejné podmínky. Hlavním cílem investičních stimulů bylo přilákat zahraniční firmy, a tím přilákat do dané země zahraniční kapitál. Zahraniční investoři se zejména zaměřili na přímý prodej zahraničním investorům. Postupně s cílem přilákat zahraniční investory a urychlit tak restrukturalizaci, byly vytvořeny systémy investičních stimulů, které měly za následek přilákat zahraniční investice na zelené louce a urychlit restrukturalizaci. V počátku nového tisíciletí nadále přetrvávala privatizace velkých firem a bankovních institucí.

Postupně se zlepšovala politická a ekonomická situace v zemi, což se odrazilo na zvýšeném zájmu zahraničních investorů, a to nejen o PZI realizované formou privatizace, ale také o PZI 
na zelené louce. Postupně se PZI rozšiřovaly ve všech odvětvích ekonomiky. V ČR do roku 1998 prŕliv PZI byl jen pozvolný s výjimkou roku 1995. Kupónová privatizace byla zpočátku prezentovaná jako jednoduchá a rychlá cesta pro zbohatnutí občanů státu, protože majitelem kuponových knížek se stávali běžní občané. Tato forma privatizace však nepřinesla do privatizovaných firem nový kapitál či know-how potřebný na jejich restrukturalizaci.

V roce 2000, 2001, a 2002 v důsledku významných privatizací v bankovním sektoru a energetice pokračoval růst př́livu PZI. V roce 2002 nejvyšší podíl zaujala privatizace českého Transgasu, což je německá společnosti RWE, která byla v hodnotě 3,7 mld. USD. Další významné PZI byly zaznamenány v oblasti automobilového průmyslu a často se jednalo o PZI na zelené louce. Např́íklad v roce 2002 byla zahájena výstava závodu Toyota ve spolupráci s PSA Peugeot Citroen v Kolíně a v roce 2007 byla zahájena výstavba automobilky Hyundai v Nošovicích. S výstavbou automobilek také souvisí vznik velkého množství dalších firem, které jsou spjaty s automobilovým průmyslem. Například vznikají externí právní firmy, které zajišt'ují právní služby, dopravní společnosti, které zajišt'ují dopravu a proclení a spoustu dalších firem, které vyrábějí komponenty pro automobilky. V roce 2006 se začaly rozšiřovat investice v oblasti strategických služeb například IBM Global Services Delivery Center Czech Republic. Také vznikla firma Visteon-Autopal, která se zaměřuje na vývoj komponentů pro automobilový průmysl. V ČR v posledních letech byl zaznamenán výraznější př́liv investic v oblasti výzkumu, vývoje a strategických služeb než v oblasti výroby. Jedná se o investice s vyšší přidanou hodnotou, ale s nižním objemem vloženého kapitálu. Právní rámec a podpora státu ve formě IP je ošetřena v zákonu o IP. Tento zákon se v průběhu času vyvíjel a reaguje na nově vzniklé právní předpisy. Zákon o IP vznikl v únoru 2000. (Zákon č. 72/2000 Sb.) Tento zákon upravuje všeobecné podmínky pro poskytování IP, postup při poskytování investičních pobídek a výkon státní správy s tím související. V oblasti legislativy IP došlo ke změně 2. 5. 2007, kdy prošla sněmovnou novela zákona o IP, která vnesla do dosavadního systému podpory investic podstatné změny. Např́iklad lepší dosažitelnost IP a jejich nasměrování do technologicky náročných odvětví. V roce 2015 vznikla novelizace tohoto zákona o IP. (Zákon č. 84/2015). Změna byla vyvolána reakcí na nové právní předpisy EU pro oblast veřejné podpory, které přinesly do systému IP zásadní změny.

Obrázek 1: Stav PZI v ČR v letech 2004-2016 (v mld. CZK)

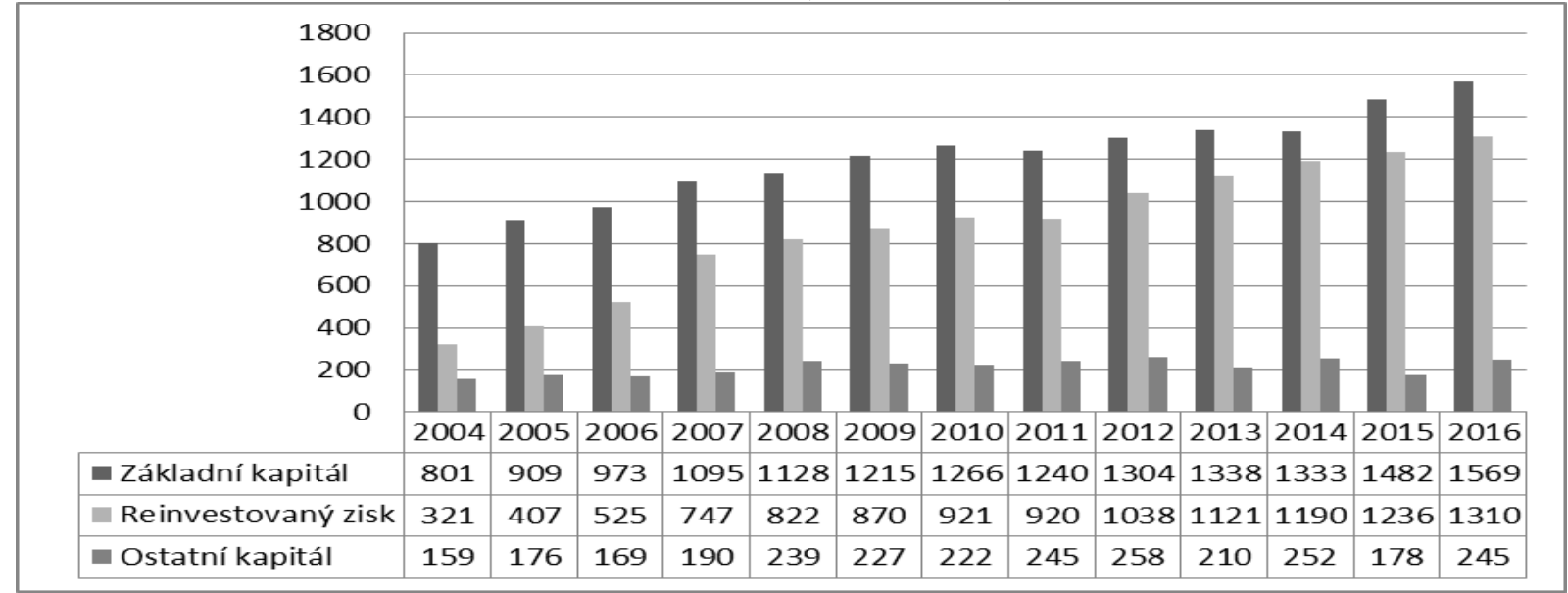

Zdroj: ČSU; vlastní zpracování

$\mathrm{Z}$ obrázku č. 1 vyplývá, že $\mathrm{v}$ rámci komponentu reinvestovaného zisku došlo k nárůstu o 989mld. CZK a položka ostatního kapitálu se zvýšila o 86mld.CZK. 
Největší objem základního kapitálu byl investován $\mathrm{v}$ oblasti finančních a pojištovacích služeb. Byl zaznamenán 10,5\% meziroční nárůst mezi lety 2004 a 2016. Dle vypracované analýzy vývoje PZI v průběhu let 2004 až 2016 lze konstatovat, že PZI mají v posledních třrinácti letech stoupající trend, což svědčí o rostoucím zájmu zahraničních investorů investovat do ČR.

Obrázek 2: PZI a IP dle země původu za období 2004-2017

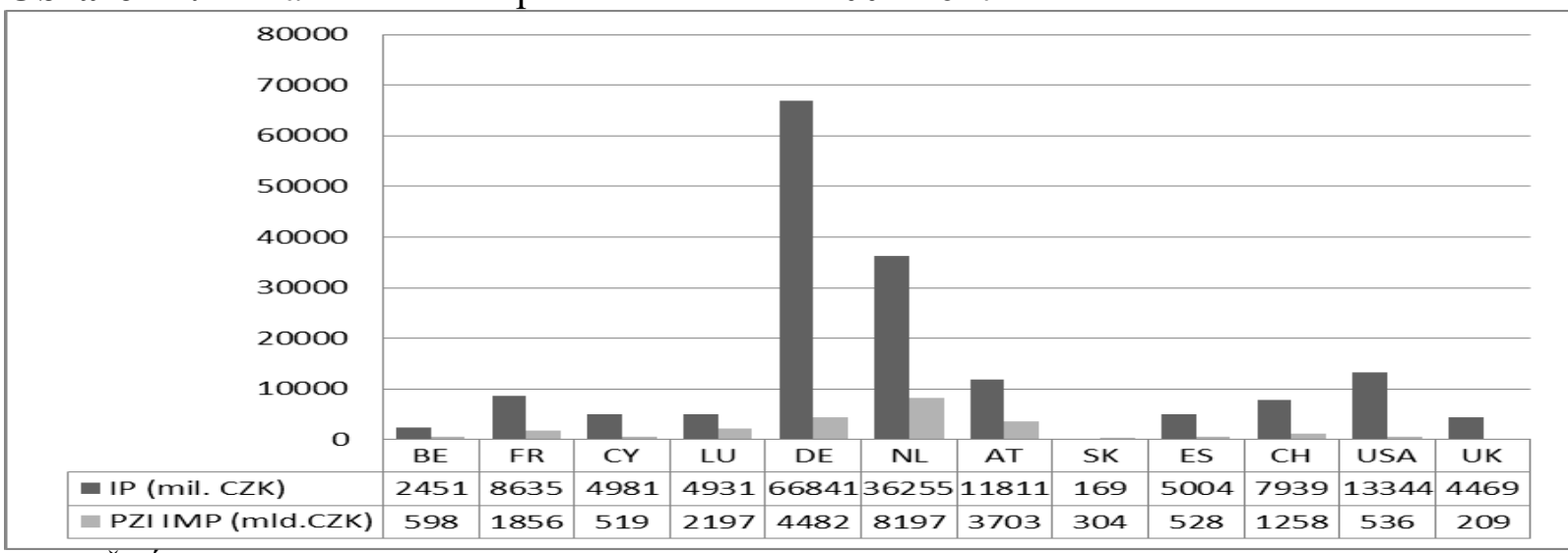

Zdroj: ČSÚ; vlastní zpracování

Na obrázku č. 2 jsou uvedeny hodnoty zkoumaných veličin, a to IP a import PZI. Za sledované období PZI činily celkem 24387mld. CZK. V této hodnotě je zahrnut základní kapitál, reinvestovaný zisk a ostatní kapitál. Mezi čtyři nejvýznamnější státy, které mají podíl na této hodnotě př́livu PZI do ČR jsou: Nizozemí (NL) ve výši 8197mld. CZK, Německo (DE) v hodnotě 4482mld. CZK, Rakousko (AT) 3703mld. CZK, Lucembursko (LU) 2197mld. CZK. V ČR se za dané období čerpalo IP celkem 166829mil. CZK. Nejvíce IP čerpalo Německo v hodnotě 66841,03mil. CZK. Pak následovalo Nizozemí (NL) 36254,98mil. CZK, USA 13343,82mil. CZK a Rakousko (AT) 11811mil.CZK.

Tabulka 1: PZI v ČR dle odvětvové struktury v letech 2004-2017 (v \%)

\begin{tabular}{|c|c|c|c|c|c|c|c|c|c|c|c|c|c|c|}
\hline NACE & Odvětví & 2004 & 2005 & 2006 & 2007 & 2008 & 2009 & 2010 & 2011 & 2012 & 2013 & 2014 & 2015 & 2016 \\
\hline K64 & $\begin{array}{l}\text { Finanční a } \\
\text { pojišt́.služby }\end{array}$ & 16,5 & 18,8 & 16,8 & 14,2 & 18,8 & 20,4 & 21,0 & 21,2 & 21,7 & 27,9 & 25,4 & 27,3 & 27,0 \\
\hline L68 & $\begin{array}{l}\text { Činnosti v oblasti } \\
\text { nemovitostí }\end{array}$ & 11,3 & 12,3 & 14,3 & 37,5 & 16,3 & 16,2 & 8,8 & 8,5 & 8,2 & 6,8 & 7,1 & 7,3 & 8,3 \\
\hline G45 & $\begin{array}{l}\text { Velkoobchod, } \\
\text { malooobchod, }\end{array}$ & 12,9 & 9,8 & 10,2 & 9,7 & 9,8 & 9,9 & 10,8 & 10,5 & 10,7 & 10,1 & 10,7 & 9,9 & 10,3 \\
\hline C29 & Motorová vozidla & 7,5 & 9,2 & 9,4 & - & 8,8 & 8,5 & - & - & - & - & - & - & - \\
\hline D35 & $\begin{array}{l}\text { Výroba a rozvod } \\
\text { elekřiny, plynu, tepla }\end{array}$ & 6,7 & 5,7 & 9,0 & 18,3 & 7,8 & 8,0 & 7,2 & 7,6 & 5,3 & 4,9 & 3,1 & 3,1 & 3,2 \\
\hline $\mathrm{H} 49$ & Doprava a telekom. & 6,2 & 12,1 & 7,6 & 4,2 & 6,8 & 5,2 & - & - & 2,6 & - & - & - & - \\
\hline J61 & $\begin{array}{l}\text { Zpracování ropy, } \\
\text { chem.výr. }\end{array}$ & - & 5,7 & 5,7 & 8,0 & 4,8 & 4,4 & - & - & - & - & - & - & - \\
\hline $\mathrm{C} 25$ & Kovy, kovové výrobky & 5,3 & 4,8 & 3,8 & 1,4 & 4,5 & 3,6 & - & - & - & - & - & - & - \\
\hline & Ostatní & 33,6 & 21,6 & 23,2 & 6,7 & 22,4 & 23,8 & 8,2 & 8,3 & 9,0 & 6,7 & 7,2 & 6,4 & 6,0 \\
\hline $\mathrm{J} 58$ & IT a komunikační činn & - & - & - & - & - & - & 6,5 & 5,7 & 5,0 & 4,9 & 5,0 & 5,8 & 5,8 \\
\hline M69 & $\begin{array}{l}\text { Profesní, vědecké a } \\
\text { techn.činn. }\end{array}$ & - & - & - & - & - & - & 4,9 & 4,0 & 4,4 & 3,7 & 5,6 & 5,1 & 5,5 \\
\hline L68 & $\begin{array}{l}\text { Soukromý nákup a } \\
\text { prodej nemovitosti }\end{array}$ & - & - & - & - & - & - & - & - & - & 2,8 & 2,5 & 2,2 & 2,3 \\
\hline $\mathrm{C} 10$ & Zpracovatelský prům. & - & - & - & - & - & - & 29,9 & 31,7 & 33,1 & 32,2 & 33,4 & 32,9 & 31,6 \\
\hline B5 & Těžba nerostů & - & - & - & - & - & - & 2,7 & 2,5 & - & - & - & - & - \\
\hline
\end{tabular}

Zdroj: ČSU; vlastní zpracování 
V tabulce č. 1 lze vidět, že př́liv PZI v ČR zaznamenal velké změny v seskupení odvětvové struktury, které bylo zapříčiněno vývojem ekonomické situace v ČR a také tím, že docházelo $\mathrm{k}$ transformaci podnikatelského prostředí. Od roku 2010 přibyla velká část PZI v oblasti finančních a pojišt'ovacích služeb a ve zpracovatelském průmyslu.

Pro zahraniční investory byl zpracovatelský průmysl velmi lákavý a od roku 2010 do roku 2014 měl rostoucí vývoj, ale v posledních dvou letech mírně klesá.

Obrázek 3: Podniky pod zahraniční kontrolou a PZI v ČR za období 2004-2017

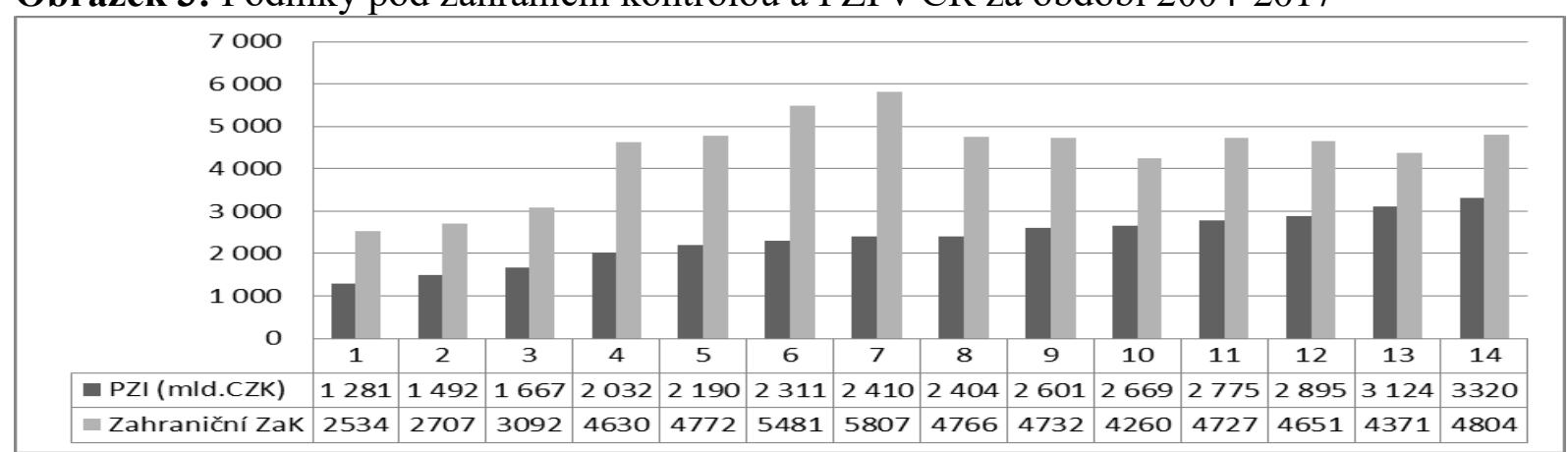

Zdroj: ČSÚ; vlastní zpracování

Dle obrázku č. 3 můžeme konstatovat, že v celém sledovaném období mají PZI stoupající tendenci. Od roku 2004 se PZI zvyšují každým rokem kdy od původních 1281mld. CZK stouply do roku 2017 na 3320mld. CZK. Výsledky ukazují pozitivní vývoj pŕílivu PZI a vzrůstající počet zahraničních investorů. $Z$ výsledků lze předpokládat, že ČR je atraktivní pro zahraniční investory. Celkový růst zahraničních společností z celkového počtu 2534 podniků v roce 2004 až na 4804 podniků v roce 2017, činilo celkem nárůst o 2270 zahraničních firem.

Tabulka 2: Podniky pod zahraniční kontrolou dle počtu zaměstnanců 2004-2017

\begin{tabular}{|l|c|}
\hline Podniky dle počtu zaměstnanců & Počet podniků \\
\hline Mikro podniky & 49060 \\
\hline Malé podniky & 7917 \\
\hline Střední podniky & 3788 \\
\hline Velké podniky & 570 \\
\hline
\end{tabular}

Zdroj: ČSÚ; vlastní zpracování

Za období 2004 až 2017 vzniklo celkem 61335 podniků pod zahraniční kontrolou. Podniky dle počtu zaměstnanců jsou uvedeny v tabulce č. 2: malých podniků vzniklo 7917 , což bylo $13 \%$ z celkově vzniklých podniků. Střední podniky tvoří $6 \%$, což je 3788 podniků, velkých podniků vzniklo 570, což tvoří $1 \%$ z celkového počtu a mikro podniků vzniklo 4906, což tvořilo $80 \%$ podniků pod zahraniční kontrolou za sledované období. Velké podniky, přestože tvoří z celkového počtu vzniklých firem pouze $6 \%$ podíl z celkového počtu zahraničních firem, tak tyto společnosti přinášejí největší podíl PZI v základním kapitálu a reinvestovaném zisku. Je pravděpodobné, že malé firmy vznikají ve větším množství než velké firmy. Protože, zprovoznění velkého podniku s více než 250 zaměstnanci je mnohem časově a finančně náročnější než zprovoznění středního, malého nebo mikro podniku. V daném období velké podniky byly zejména ze zpracovatelského průmyslu, velkoobchodu a maloobchodu. 
Obrázek 4: Import PZI a čerpané IP dle země původu 2004-2017 (v \%)

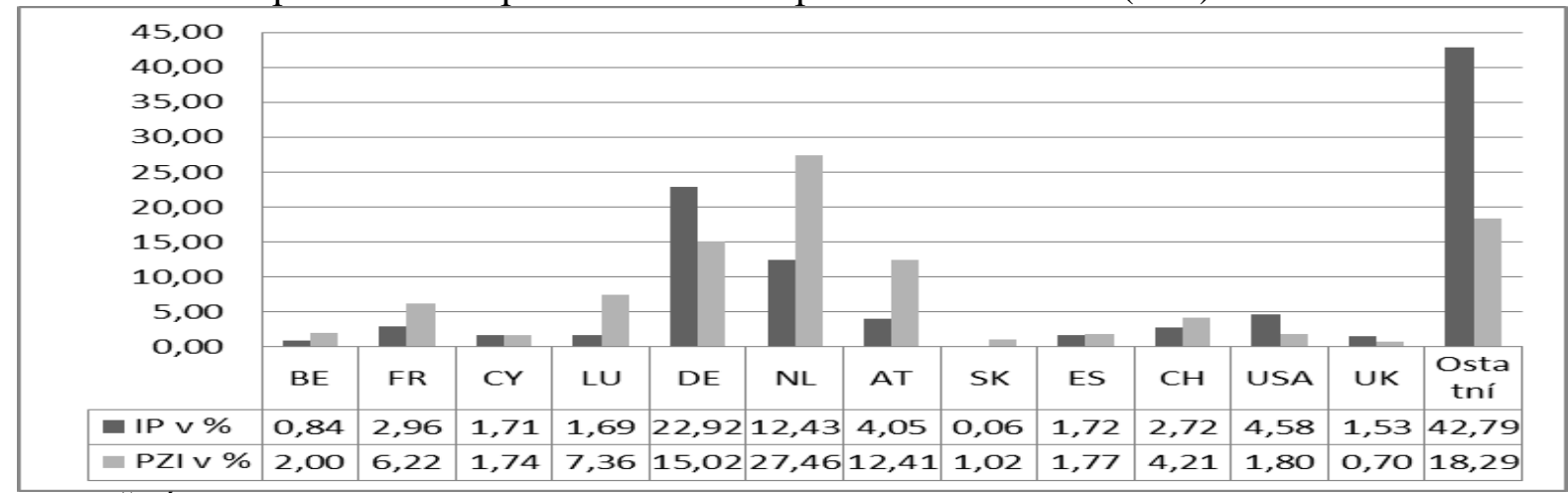

Zdroj: ČSÚ; vlastní zpracování

PZI a IP za období 2004 až 2016 dle teritoriálního členění byly analyzovány na obrázku 4. Celkové PZI dosahovaly hodnoty 29845,80 mld. CZK. Celkové IP dosahovaly hodnoty 291573mil. CZK. Graf č. 4 uvádí procentuální vývoj těchto veličin. Největší podíl na objemu PZI zaujímalo Nizozemí ve výši $27,46 \%$ následované Německem ve výši $15,2 \%$, Rakouskem ve výši $12,41 \%$ a zbývající země investovaly $45 \%$. Celkové IP jsou graficky rozděleny dle země původu. Největší množství IP čerpalo Německo ve výši 22,92\% a Nizozemí ve výši $12 \%$, což je 103096 mil. CZK. IP ostatních zemí se pohybovaly mezi $0,84 \%$ až 4,05\% z celkových investic. Zbývající země investovaly 64\%, což je 188477 mil. CZK.

\section{Závěr}

Cílem článku bylo zjistit, jak se vyvíjely PZI, IP a podniky pod zahraniční kontrolou za období 2004-2017 v ČR. Zaznamenané změny výše zmíněných veličin v tomto závěru jsou okomentovány dle stanoveného cíle. Od roku 1989 byl zaznamenán nedostatek kapitálu a nových technologií, kdy v této době byly také vytvořeny podmínky pro investice a zaváděly se investiční smlouvy. Investiční stimuly byly tvořeny tak, aby domácí i zahraniční investoři měli stejné podmínky. Postupně se PZI rozšiřovaly do různých odvětví ekonomiky. V roce 2000 až 2002 pokračoval růst PZI v bankovním sektoru a energetice. V roce 2007 se investice soustřed'ovaly do automobilového průmyslu. Začaly se také rozšiřovat investice v oblasti strategických služeb. V posledních letech přitékalo nejvíce investic do oblasti výzkumu a vývoje. Zákon o investičních pobídkách vznikl v únoru 2000, ale v roce 2007 byl novelizován a v roce 2015 vznikla nová novelizace tohoto zákona o investičních pobídkách vyvolaná reakcí na nové právní předpisy. V období 2004 až 2017 byl největší objem kapitálu investován v oblasti služeb finančních a pojišstovacích.

V ČR firmy s podporou IP investovaly 299293,57 mil. CZK. Největší podíl na této hodnotě dle země původů mělo Německo 40\%, Nizozemí 22\%, Rakousko $7 \%$ a pak následovaly ostatní země, které investovaly díky pobídkám celkem $23 \%$ v rozmezí od $1 \%$ do $5 \%$. Za sledované období vzniklo celkem 61335 podniků pod zahraniční kontrolou a tvořily 49060 mikro podniků dle počtu zaměstnanců, což bylo $80 \%$ z celkového počtu zahraničních podniků. Malé podniky zaujímaly $13 \%$, což bylo 7917 podniků, střední podniky $6 \%$, což bylo 3788 podniků a velké podniky 570 podniků, což činilo $1 \%$ z celkového počtu podniků pod zahraniční kontrolou. Dle zjištěných výsledků lze usoudit, že velké zvýšení investic má vazbu na odběratelské a dodavatelské vztahy napříc firmami v ČR, a tím přispívají k lepšímu konkurenčnímu prostředí. Př́liliv PZI také zaznamenal velké změny ve struktuře odvětví, což bylo důsledkem transformace podnikatelského prostředí v otevřené ekonomice. V letech 2010 až 2016 ve zpracovatelském průmyslu se pohybovaly investice mezi 29,9\% až 33,4\%. 
Za sledované období tvořily PZI 24387 mld. CZK a přilákalo investory z těchto zemí: Nizozemí investovalo ve výši 8197 mld. CZK, což bylo 34\% z celkových PZI. Německo investovalo $18 \%$, což činilo $4482 \mathrm{mld}$.CZK, pak následovaly investice Rakouska v hodnotě $3703 \mathrm{CZK}$, což bylo 15\%. Francie investovala 1856 mld. CZK, což bylo $8 \%$ PZI z celkových PZI za období 2004-2017. PZI jsou jeden ze způsobu přenosu technologií a lze dle velkého množství investic za dané období soudit, že ČR je lákavou lokalitou pro Německo, Nizozemí i Rakousko. Tyto země jsou velmi vyspělé a přispívají transferem svých zkušeností ke zvyšování životní úrovně v ČR. Z Německa se dováží zejména ropa, zemní plyn, silniční vozidla a do Německa vyváźíme zejména obilí. Z Rakouska se dováží hlavně maso a potraviny. Nizozemí je pro české firmy zajímavou exportní destinací, ale je třeba podotknout, že nizozemský trh je velmi konkurenční a náročný. Nizozemí by se mělo stát novým evropským finančním centrem a bylo by prŕínosné v rámci další vědecké činnosti podrobněji prozkoumat tuto lokalitu z pohledu importu i exportu. Podrobnou analýzu Německa i Rakousko z pohledu exportu i importu by bylo vhodné také prozkoumat a vzájemně tyto země porovnat dle jednotlivých ukazatelů s použitím matematicko-statistických metod.

Dle zjištěných výsledků IP a PZI dosahovaly vysokých hodnot, a tím přispěly k rozvoji ekonomiky země. Závěrem lze konstatovat, že ČR získala velké zkušenosti v oblasti investic a je schopna přilákat spoustu zahraničních investorů. Tyto skutečnosti jsou pozitivní pro ekonomický rozvoj a ovlivňuji podnikatelské prostředí. Podrobná analýza vývoje PZI a IP bude také východiskem pro disertační práci, ve které tato problematika bude podrobně zkoumána se zaměřením na vliv podnikatelského prostředí.

Z výsledku zkoumaných veličin lze vyvodit doporučení pro další podrobné výzkumy. Z pohledu př́livu PZI by bylo vhodné zjistit, jaké vznikají spillover efekty v rámci dovozu do ČR. Také by bylo velmi př́nosné prozkoumat vliv těchto efektů na domácí konkurenční prostředí, a jak se vývoj zkoumaných veličin podílel na vývoji životní úrovně v ČR. Popř́ṕpadě zjistit jak se projeví vzájemné vazby u sledovaných ukazatelů ve zvolených zemích

\section{Literatura}

[1] ASIEDU, E., 2002. On the Determinants of Foreign Direct Investment to Developing Countries: Is Africa Different? World. PII: S0305-750X(01)00100-0.

[2] BACKER, K. and L. SLEUWAEGEN, 2003. Does Foreign Direct Investment Crowd Out Domestic Entrepreneurship? Review of Industrial Organization, vol. 22, s. 67 - 84. ISSN 1573-7160.

[3] BANGA, R., 2003. Impact of Government Policies and Investment Agreements on FDI Inflows. ICRIER Working Paper No. 116. New Delhi: Indian Council for Research on International Economic Relations.

[4] BEGG, H. M. and S. McDOWALL, (1987), The Effect of Regional Investment Incentives on Company Decisions, Regional Studies, 21, pp.459-470.

[5] BILINGTON, N., 1999. The Location of Foreign Direct Investment: An Empirical Analysis. Applied Economics, 31(1), 65-76.

[6] BLOMSTORM, M. and A. KOKKO, (1998), Multinational Corportions and Spillovers. Journal of Economic Surveys, vo. 12, s.245_277. ISSN 0950-0804.

[7] BRAINARD, S. L. (1997), "An Empirical Assessment of the Proximity-Concentration Trade-off between Multinational Sales and Trade", American Economic Review, Vol. 87. 
[8] CLEEVE, E., 2008. How effective are fiscal incentives to attract FDI to Sub-Saharan Africa? United Kingdom: Manchester Metropolitan University.

[9] CULEM, C. G, 1988. The Location Determinants of Direct Investments: Among Industrialized Countries. European Economic Review, 32 (4), 885-904.

[10] DJANKOV, S. and B. HOEKMAN, 2000. Foreign Investment and Productivity Growth in Czech Enterprises. World Bank Economic Review, vol. 14, s. 49 - 64. ISSN 1564$698 X$.

[11] DRÁBEK, J., 2007. Komora.cz-měsičník Hospodářské komory ČR, č.10/2007.

[12] EVROPSKÁ KOMISE, 2015. Uživatelská př́ručka $k$ definici malých a středních podniků. Úřad pro publikace Evropské unie, ISBN 978-92-79-45310-6.

[13] FEENSTRA, R. C. and G. H. HANSON, (1996), "Globalisation, Outsourcing and Wage Inequality", American Economic Review, Vol. 86, (2,Papers and Proceedings).

[14] GOLDBERG, L. S. and M. W. KLEIN, (1997), "Foreign Direct Investment, Trade and Real Exchange Rate Linkage in Southeast Asia and Latin America", NBER Working Paper, No. 6344.

[15] HAUFLER, A. and I. WOOTON, 1999. Country Size and Tax Competition for Foreign Direct Investment. Journal of Public Economics, 71 (1), 121-139.

[16] HARDING, T. and B. JAVORCIK, 2007. Developing economies and international investors: do investment promotion agencies bring them together? Policy Research Working Paper 4339. Woshington, D.C.: The world Bank Development Research.

[17] HANSON, G., (2000), Should Countries Promote Foreign Direct Investment?", paper prepared for $\mathrm{G} 24$.

[18] HOLMAN, R., (2004). Makroekonomie: středně pokročilý kurz. 1.vydání C.H.Beck. Praha, ISBN: 80-7179-764-2.

[19] CHAKRABARTI, A., 2001. The Determinant of Foreign Direct Investment: Sensivity Analysses of Cross-Country Regression. Kyklos, 54 (1), 89-114.

[20] CHALK, N., 2001. Tax incentives in the Philippines: A regional perspective. IMF Working Paper No. 01/181. Washington, D.C.: International Monetary Fund - Asia and Pacific Department

[21] JAHN, M., 2008. Význam zahraničních investic pro českou ekonomiku. (člen představenstva Škoda Auto,a.s.

[22] KONINGS, J., 2000. The Effects of Foreign Direct Investment on Domestic Firms: Evidence from Firm Level Panel Data in Emerging Economies [online]. CEPR Discussion Paper Serries No. 2586,

[23] KOSOVÁ, R., 2010. Foreign Firms Crowd Out Domestic Firms? The Review of Economics and Statistics, 2010, vol. 92, No. 4, s. 861 - 881. ISSN 0043-6535.

[24] KUNEŠOVÁ, H., 2014. Světová ekonomika: nové jevy a perspektivy. 3.přepracované a doplněné vydání. Praha: C.H.Beck, 2014. ISBN 978-80-7400502-2.

[25] LAHIRI, S. and Y. ONO, 1996. Foreign direct investment, local contents, and profit taxation. Mimeo, University of Essex and Tokyo Institute of Technology 
[26] MADIÉS, T. and J. DETHIER, 2010. Fiscal competition in developing countries: A survey of the theoretical and empirical literature. Policy Research Working Paper 5311. Washington, D.C.: World Bank.

[27] MANASAN, R., 2002. Explaining the decline in tax effort. PIDS Policy Notes: 2002-14. Makati City: Philippine Institute for Development Studies.

[28] MARKUSEN, J. R. and A. VENABLES, 1998. "Multinational Firms and the New Trade Theory", Journal of International Economics, Vol. 46.

[29] MEDALLA, E., 2002. Fiscal incentives revisited. Philippine Journal of Development 29(2): 1-26

[30] MORISSET, J. and N. PIRNIA, 2000. How tax policy and incentives affect foreign direct investment: A review. Policy Research Working Paper 2509. Washington, D.C.: World Bank.

[31] ŘÍMAN, M., 2008. Zahraniční investice ano, pobídky ne. Ministr průmyslu a obchodu.

[32] TOMŠÍK, V., 2008. Zajistí př́mé zahraniční investice prosperitu ČR? (člen bankovní rady $\check{C} \mathrm{NB})$,

[33] ŽIGIČ, K., 1998. Strategic trade policy, spillovers, and uncertain mode of competition. CERGE-EI working paper series, s.123. Grant:GA AV CR (CZ) KSK3028601.

[34] ZAMRAZILOVÁ, E., 2008. Kam povede př́liv př́mých zahraničních investic? (Komerční banka)

[35] UNCTAD, 2000a, World Investment Report: Cross-border Mergers and Acquisitions and Development, New York and Geneva, United Nations. 